\title{
Determination of the Rational Drug Use Awareness of University Students
}

\author{
Üniversite Öğrencilerinin Akılcı İlaç Kullanma \\ Farkındalıklarının Belirlenmesi
}

Ahmet Y. Yeşildağ ${ }^{1 *}$
ORCID: 0000-0003-3116-4051
İsmail Ağırbaş²
ORCID: 0000-0002-1664-5159

Gökhan Y1lmaz ${ }^{3}$

ORCID: 0000-0002-9564-0427

${ }^{1}$ Karadeniz Technical University,
Faculty of Health Sciences, Department
of Health Management, Trabzon, Turkey

${ }^{2}$ Ankara University, Faculty of Health Sciences, Department of Health Management, Ankara, Turkey

${ }^{3}$ Karadeniz Technical University, Faculty of Health Sciences, Department of Health Management, Trabzon, Turkey

Corresponding author:

Ahmet Y. Yeşildağ

Karadeniz Technical University, Faculty of Health Sciences, Department of Health

Management, Trabzon, Turkey

E-mail: ay.yesildag@hotmail.com

Tel: +904623778842

Fax: +904622300475
DOI: 10.52794/hujpharm.1024991

\begin{abstract}
Non-rational drug use harms both health and the economy. This study aims to evaluate the rational drug use awareness of undergraduate students studying in two faculties where future health professionals are trained. The study was carried out with 449 undergraduate students studying at Karadeniz Technical University (KTU) Faculty of Health Sciences and Faculty of Pharmacy. As a data collection tool, the "Consciousness Scale Towards Rational Drug Use (CRDU) in Adults" was developed by Aktas and Selvi. The descriptive information form consisting of 6 questions was used. SPSS 23 program was used for data analysis. Of the 449 students participating in the study, 193 (43\%) are pursuing bachelor's degrees in Nursing, 160 (35.6\%) in Pharmacy, and 96 (21.4\%) in Health Management. It was determined that the student's awareness of rational drug usage was $\tilde{x}=4.19$ / $\mathrm{s}=0.44$. It is thought that the students participating in the study had a relatively good level of awareness of the study findings that discussed in the literature. However, in the correct drug awareness dimension, it is seen that there are inadequacies in the fact that the drug recommendations from non-physician health personnel can also be taken into account. It is recommended to carry out studies in which the attitude, awareness or knowledge level of rational drug use is measured through valid and reliable scales.
\end{abstract}

Keywords: Rational Drug Use, Drugs, Health Occupations Students

\section{ÖZET}

Akılcı olmayan ilaç kullanımı hem sağlı hem de ekonomi üzerinde olumsuz bir etkiye sahiptir. Bu çalışmada geleceğin sağlık profesyonellerinin yetiştiği iki fakültede öğrenim gören lisans öğrencilerinin akılcı ilaç kullanım farkındalıklarının değerlendirilmesi amaçlanmıştır. Çalışma Karadeniz Teknik Üniversitesi Sağlık Bilimleri Fakültesi ve Eczacılık Fakültesi'nde eğitim gören 449 lisans öğrencisi ile gerçekleştirilmiştir. Veri toplama aracı olarak Aktaş ve Selvi tarafından geliştirilen "Erişkinlerde Akılcı İlaç Kullanım Farkındalık (AİKF) Ölçeği ve 6 sorudan oluşan tanımlayıcı bilgi formu kullanılmıştır. Verilerin analizinde SPSS 23 programı kullanılmıştır. Çalışmaya katılan 449 öğrencinin 193 'ü (\%43) Hemşirelik, 160'1 (\%35,6) Eczacılık, 96’s1 (\%21,4) Sağlık Yönetimi Bölümü'nde lisans eğitimi almaktadır. Öğrencilerin akılcı ilaç kullanma farkındalığı düzeyinin $\overline{\mathrm{x}}=4,19$ / s=0,44 olduğu saptanmıştır. Çalışmaya katılan öğrencilerin literatürde 
tartışılan çalışma bulgularıyla görece olarak iyi bir farkındalık düzeyine sahip olduğu düşünülmektedir. Ancak doğru ilaç farkındalığı boyutunda hekim dışı sağlık personelinin ilaç tavsiyelerinin de dikkate alınabileceği konusunda yetersizliklerin olduğu görülmektedir. Akılcı ilaç kullanımı tutum, farkındalık veya bilgi düzeyini geçerli ve güvenilir ölçekler aracılığıyla belirleyen bilimsel çalışmaların yapılması önerilmektedir.

Anahtar kelimeler: Akılcı İlaç Kullanımı, İlaç, Sağlık Mesleği Öğrencileri

\section{Introduction}

The aging of the population and the increase in the weight of non-communicable and chronic diseases in the burden of disease are changing the health service delivery needs. In parallel with the developments in medicine, the financial burden in health services and the share allocated to drugs are increasing. Therefore, rational use of drugs and treatment becomes more important [1,2]. It is stated that although non-rational drug use is predominant in developing countries, it is a habit that is experienced all over the world and is difficult to correct. This problem can lead to deaths, waste of resources, and inequalities. It is thought that indirect goals such as raising awareness of rational drug use and direct policy interventions are involved in solving the problem [3].

Ambwani and Mathur [4] define the rational drug use as "prescribing right drug in adequate dose for the sufficient duration \& appropriate to the clinical needs of the patient at lowest cost" by referring to the view of Herophilus, an Alexandrian physician in BC 300 that the drugs would be effective if used with reason and common sense. After the World Health Organization conference on rational drug use in Nairobi, Kenya in 1985, awareness of rational drug use increased [5].
It is expressed that factors that reveal the use of nonrational drugs are factors such as lack of information, problems in medical education, problems in personnel-patient communication, inability to diagnose correctly, and factors such as drug printing pressures, lack of legislation, and marketing of pharmaceutical companies [4]. Non-rational drug use and ineffective and unsafe treatment can lead to unintended consequences such as exacerbation or prolongation of the disease, increased stress and pain of the patient, and increased cost of treatment [4]. Rational drug use requires individuals to take the right drug at the correct dose, with sufficient time, and at the lowest cost. Otherwise, it can harm both health and economy [6]. Aktas and Selvi [7] map these adverse effects of non-rational drug use with the information compiled from the literature.

As stated, non-rational drug use can lead to many political, social, political, economic, and biological problems. Semin [8] provides some examples of studies involving rational drug use and its effects in the world. For example, the necessity of the drugs prescribed in Germany was discussed, and 30\% were calculated to be unnecessary. In Canada, approximately $50 \%$ of the drugs are not appropriately used, and the approximate annual cost of these non-

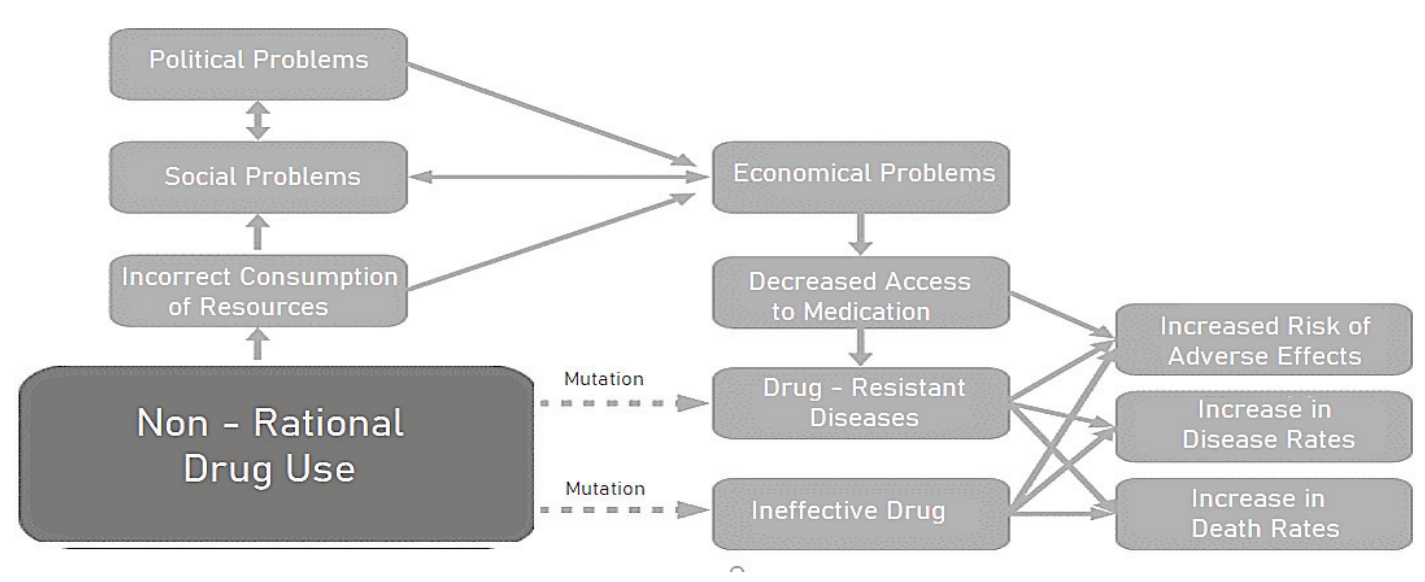

Figure 1. Effect of Non - Rational Drug Use [7] (Reprint with permission) 
rational uses is estimated at $\$ 9$ billion, which is more than Turkey's health expenditure at the time. Semin [8] also states that $8 \%$ of hospital admissions in the U.S. are caused by adverse drug reactions, bringing the number of deaths to about 150,000 people a year.

Health workers, society, and regulatory authorities play a role in rational drug use. Health workers have roles such as deciding the proper treatment, selecting the drug, informing patients and their relatives, administering the drug, managing drug waste, monitoring the treatment process and outcome, and counseling. Patients and their relatives have responsibilities such as not demanding unnecessary drugs, helping to make correct diagnoses, taking an active role in treatment, paying attention to recommendations and warnings, and not obtaining information from unreliable sources [9].

If the parties' roles are examined through the use of antibiotics, in 2015, Turkey ranked first among Organisation for Economic Co-operation and Development (OECD) countries with a percentage of 41.1 (OECD average 20.5) in terms of defined daily antibiotic dose use [10]. On the part of the medical staff, the pressure to physicians about write prescriptions, the errors of prescribing errors of newly graduated physicians, the training of prescribing skills $[3,11]$ the patient-physician communication level and, short examination times can be considered as the cause of it [12]. Khori et al. [13] found that the rate of prescribing decreases as the examination period is prolonged. Hocaoglu et al. 's study [14] with students, can be shown as an example of the effect of rational drug prescribing skills in medical education. In the mentioned study, positive changes were observed in success levels after training on rational drug prescribing.

On the part of the patient and his relatives, it can be thought that this situation is caused by the intense drug prescription and consumption behavior in line with the information learned from wrong sources [11]. With the use of various policy instruments in Turkey, an awareness about antibiotic consumption has been created, and thanks to the participation of stakeholders, the level of daily antibiotic use per thousand people have decreased to 31 , and a better point has been reached. However, Turkey is still above the OECD average on this matter and is at the top of the list $[15,16]$.

Here are some measures to be taken to increase the level of rational drug use [17]:
- Promotional activities of pharmaceutical companies should be controlled,

- Physicians should be informed about equivalent drug use and rational prescribing,

- Applications and training to increase rational prescribing should be increased,

- Restrictions on over-the-counter drug intake should be audited,

- Informative training should be given through visual and written media to prevent the non-rational use of drugs by citizens,

- For rational drug use, the educational quality of health members should be improved, and the training programs related to the subject should be updated,

- Society should be trained in self-treatment and treatment with herbal remedies.

The eleventh development plan of the Republic of Turkey includes raising, monitoring, and evaluating rational drug use awareness [2]. This study aims to contribute to this goal in the development plan and to determine the awareness of rational drug use of students receiving undergraduate education in two faculties where future health professionals are trained.

\section{Material and Methods}

To determine university students' awareness of rational drug use, the population of this cross-sectional and descriptive study is made up of 1,396 undergraduate students studying at Karadeniz Technical University (KTU) Faculty of Health Sciences and Faculty of Pharmacy. The required sample size was estimated at 302 people using the formula $n=\left[z^{2} \times p(1-p) /\right.$ $\left.\mathrm{d}^{2}\right] / 1+\left[\mathrm{z}^{2} \mathrm{xp}(1-\mathrm{p}) / \mathrm{d}^{2} \mathrm{~N}\right]$. The calculation was done at $\mathrm{p}=0.05$ in the $95 \%$ confidence interval with the sample calculation engine through the surveymonkey. com website. The study data was collected through a link to students online through Google Forms. In the study, 449 valid data were obtained. In the study, the "Consciousness Scale Towards Rational Drug Use (CRDU) in Adults" measuring 5-point Likert type developed by Aktaş and Selvi (2019) and a descriptive information form consisting of 6 questions were used as data collection tools [7]. There are 15 items on the scale and three dimensions consisting of "correct information awareness," "correct drug aware- 
ness," and "correct usage awareness". The first eight items on the scale consist of inverted questions, and the answers to these items were reversed while the analysis was being carried out. During the data collection phase of the study, the necessary permissions were obtained from the scale holder and the relevant institutions. Ethical approval was obtained from the Scientific Research Ethics Committee of KTU Faculty of Medicine (N:24237859-729 D:29.09.2021). SPSS 23 program was used in the analysis of the obtained data. When comparing the mean of the two independent groups, a t-test was used, and the ANOVA test was used when comparing the mean of more than two groups. The Mann-Whitney U test and KruskalWallis test were used to analyze the dimension of "correct usage awareness," which is not assumed to be generally distributed based on the skewness and kurtosis values. The Pearson Chi-Square test was conducted to determine whether there was a difference between the students agreeing that expensive drugs were more effective and preferring equivalent drugs within the scope of reimbursement, according to their departments.

During the development phase of the scale used in the research, its validity and reliability were tested in adults without any limitations in terms of a demographic variable such as occupation and education level. Although the sample groups were not completely separated from each other, the structure developed by Aktas and Selvi [7] on the sample of this study was tested with Confirmatory Factor Analysis. Analysis was done with SPSS AMOS 24 program.

\section{Results and Discussion}

In this section, the data obtained from 449 students studying at the undergraduate level at KTU Faculty of Health Sciences and Faculty of Pharmacy, voluntarily agreed to participate in the study will be presented in tables.

Table 1. Distribution of participants by socio-demographic characteristics

\begin{tabular}{|c|c|c|c|}
\hline \multicolumn{2}{|l|}{ Variables } & \multirow{2}{*}{$\begin{array}{c}\mathbf{n}(449) \\
160\end{array}$} & \multirow{2}{*}{$\begin{array}{c}\mathbf{\%} \\
35.6\end{array}$} \\
\hline & Pharmacy & & \\
\hline \multirow[t]{2}{*}{ Department } & Nursing & 193 & 43.0 \\
\hline & Health Management & 96 & 21.4 \\
\hline \multirow{3}{*}{ Gender } & Female & 370 & 82.4 \\
\hline & & & \\
\hline & Male & 79 & 17.6 \\
\hline \multirow{5}{*}{ Grade } & $1^{\mathrm{st}}$ & 124 & 27.6 \\
\hline & $2^{\text {nd }}$ & 85 & 18.9 \\
\hline & $3^{\text {rd }}$ & 109 & 24.3 \\
\hline & $4^{\text {th }}$ & 111 & 24.7 \\
\hline & $5^{\text {th }}$ & 20 & 4.5 \\
\hline \multirow{3}{*}{ Regular Drug Use Status } & Yes & 67 & 14.9 \\
\hline & & & \\
\hline & No & 382 & 85.1 \\
\hline \multirow{2}{*}{$\begin{array}{l}\text { Preferring Generic Drugs within the Scope of SSI } \\
\text { Reimbursement }\end{array}$} & Yes & 350 & 78.0 \\
\hline & No & 99 & 22.0 \\
\hline \multirow{2}{*}{$\begin{array}{l}\text { Status of Thinking Expensive Medicines Are More } \\
\text { Effective }\end{array}$} & Yes & 31 & 6.9 \\
\hline & No & 418 & 93.1 \\
\hline
\end{tabular}


Table 1 shows the distribution of participants based on their socio-demographic characteristics. Accordingly, 193 (43\%) of the 449 students are studying for a bachelor's degree in Nursing, 160 (35.6\%) in Pharmacy, and 96 (21.4\%) in Health Management. Of the study participants, $370(82.4 \%)$ were female, and 79 $(17.6 \%)$ were male students. Of those students, 124 $(27.6 \%)$ were in $1^{\text {st }}$ grade, $85(18.9 \%)$ in $2^{\text {nd }}$ grade, $109(24.3 \%)$ in $3^{\text {rd }}$ grade, $111(24.7 \%)$ in $4^{\text {th }}$ grade, and $20(4.5 \%)$ in $5^{\text {th }}$ grade. Of the participating students, 67 (14.9\%) took regular medication, while 382 $(85.1 \%)$ did not take regular medication. The number of students who opted for equivalent drugs covered by Social Security Institution (SSI) reimbursement was $350(78 \%)$, while the number of students who did not prefer that was 99 (22\%). Thirty-one (6.9\%) students think expensive drugs are more effective, while 418 (93.1\%) do not think so.

Table 2 shows the kurtosis and skewness values of CRDU Scale. Since the kurtosis and skewness values between $-1.5 /+1.5$ in measurement studies on individuals are considered sufficient for the assumption of normal distribution [18], the study data were tested through parametric tests, except for the "correct usage awareness" dimension. For the "correct usage awareness" dimension, hypothesis tests were conducted with non-parametric methods.

In Table 4, the minimum and maximum values, means, standard deviation values, and Cronbach's alpha $(\alpha)$ coefficients are presented for rational drug use awareness and its dimensions. Accordingly, it was determined that the rational drug use awareness level of the students participating in the study was $\bar{x}=4.19$. In addition, it was determined that the level of the student with the lowest awareness of rational drug usage was $\overline{\mathrm{x}}=2.33$, and the level of the student with the highest was $\bar{x}=5.00$. The scale's overall
Cronbach's alpha $(\alpha)$ coefficient was calculated as 0.732 . It is seen that the coefficient is at a reasonable level in terms of scale reliability [19].

Confirmatory factor analysis was performed to test the compatibility of the scale components with the original structure (Table 3 ). It is seen that the data obtained from the sample in our study is compatible with the original structure of the scale. Model fit values that are frequently checked in structural equation models and confirmatory factor analyzes are $\mathrm{x} 2 / \mathrm{df}$ (Relative Chi-Square Index), GFI (Goodness of Fit Index), CFI (Comparative Fit Index) and RMSEA (Approximate Root Mean Square Error of Approximation) [20]. According to Karagöz [20], the values in the measurement are in perfect fit with the original model. Although it is not used as often as the others, the NFI (Normed Fit Index) value is expected to be above 0.90 . However, it is seen that the model is compatible due to the acceptance of 0.88 fit level in some scale adaptation studies [21]. It was observed that the loading coefficients of the 5th and 13th items in the scale were partially low. However, since the statements did not have an effect on the internal consistency coefficient and the fit values were good, it was decided to preserve the original form of the scale by measuring with the existing statements.

Table 5 shows the mean scores of the CRDU Scale and its dimensions based on the department of the students. In line with the data in the table, no statistically significant difference was found between the levels of CRDU by department ( $>0.05)$. Statistically significant differences were found in the dimensions of the correct information and correct drug awareness when the means were compared in terms of the scale dimensions $(p<0.05)$. It was determined that pharmacy students had the highest level

Table 2. The kurtosis and skewness values of the CRDU scale and its dimensions

\begin{tabular}{lcc}
\hline CRDU Scale and Dimensions & Skewness & Kurtosis \\
\hline Correct Information Awareness & -0.849 & 0.218 \\
Correct Drug Awareness & -0.574 & -0.306 \\
Correct Usage Awareness & -3.125 & 13.529 \\
Total Scale & -0.516 & 0.231 \\
\hline
\end{tabular}


Table 3: Model Fit Values Summary

\begin{tabular}{cccccccc}
\hline CMIN & DF & $\mathbf{p}$ & CMIN/DF & GFI & CFI & NFI & RMSEA \\
\hline 184,811 & 84 & 0,000 & 2,200 & 0,94 & 0,93 & 0,88 & 0,52 \\
\hline
\end{tabular}

Table 4. Distribution of the participants' mean scores of the CRDU scale and Cronbach's alpha values of the scale

\begin{tabular}{lccccc}
\hline CRDU Scale and Dimensions & Min & Max & Mean $\overline{\mathbf{x}}$ & Sd (s) & Cronbach's Alpha ( $\alpha)$ \\
\hline Correct Information Awareness & 2.75 & 5.00 & 4.32 & 0.53 & 0.700 \\
Correct Drug Awareness & 1.00 & 5.00 & 3.50 & 1.00 & 0.757 \\
Correct Usage Awareness & 1.00 & 5.00 & 4.75 & 0.48 & 0.546 \\
Total & 2.33 & 5.00 & 4.19 & 0.44 & 0.732 \\
\hline
\end{tabular}

of awareness in the dimension of correct information awareness $(\bar{x}=4.42)$. In the dimension of correct drug awareness, Health Management students were found to have higher awareness $(\overline{\mathrm{x}}=3.81)$.

Table 5 also shows the statistical results regarding the CRDU levels of the students in terms of gender. In line with the data in the table, it was determined that the rational drug use level of women $(\overline{\mathrm{x}}=4.23)$ was higher than that of men $(\bar{x}=3.97)(p=0.001)$. When CRDU levels were examined in terms of scale dimensions, there were statistically significant differences in the correct usage awareness and the correct drug awareness dimensions. In the context of these dimensions, it has been determined that women have a higher level of awareness than men $(p<0.05)$.

In addition, Table 5 shows the statistical results regarding the CRDU levels of the students in terms of the grade they were studying in. In line with the data in the table, no statistically significant difference was found between the grades in terms of the overall CRDU levels and the scale dimensions $(\mathrm{p}>0.05)$. On the other hand, the CRDU level of the $1^{\text {st }}$ graders was $\bar{x}=4.15$, that of the $2^{\text {nd }}$ graders was $\bar{x}=4.23$, that of the $3^{\text {rd }}$ graders was $\bar{x}=4.21$, that of the $4^{\text {th }}$ graders was $\overline{\mathrm{x}}=4.20$, and that of the 5th graders was $\overline{\mathrm{x}}=4.04$.

Moreover, Table 5 presents the statistical results of the students' regular drug use levels in terms of CRDU levels. In line with the data in the table, no statistically significant difference was found regarding the overall level and the CRDU dimensions in terms of regular drug use $(p>0.05)$. In general, the reason why individuals who regularly use drugs have a higher level of awareness with small differences cannot be explained by their regular drug use status at the $95 \%$ confidence level.

Additionally, Table 5 shows the statistical results of the CRDU levels of the students in terms of their preference for equivalent drugs within the scope of the SSI reimbursement. In line with the data in the table, no statistically significant difference was found in terms of the level of CRDU and its dimensions based on students' preference for equivalent drugs within the scope of reimbursement $(\mathrm{p}>0.05)$. Although it was not statistically significant, it was determined that the mean awareness level of the students who preferred equivalent drugs $(\overline{\mathrm{x}}=4.20)$ was higher than those who did not $(\overline{\mathrm{x}}=4.16)$.

Furthermore, Table 5 presents the statistical results of the CRDU levels in terms of the students' agreement with the view that "expensive drugs are more effective." In line with the data in the table, no statistically significant difference was found between the overall CRDU levels in terms of the students' agreement with the opinion that "expensive drugs are more effective" ( $p>0.05)$. It was determined that the only significant difference in awareness level in terms of scale dimensions was in the dimension of correct information awareness, and students who thought that "expensive drugs are more effective" had a lower level of CRDU $(\mathrm{p}=0.001)$. Although it was not statistically significant, it was determined that the awareness levels of the students who disa- 
Table 5. Values of students' awareness of rational drug use in terms of various variables

\begin{tabular}{|c|c|c|c|c|c|}
\hline Variables & N (449) & $\begin{array}{l}\text { Correct Information } \\
\text { Awareness } \overline{\mathbf{x}} / \mathbf{s}\end{array}$ & $\begin{array}{r}\text { Correct Drug } \\
\text { Awareness } \overline{\mathbf{x}} \mid \mathbf{s}\end{array}$ & $\begin{array}{c}\text { Correct Usage } \\
\text { Awareness* } \overline{\mathbf{x}} \mid \mathbf{s}\end{array}$ & $\begin{array}{l}\text { Total CRDU } \\
\text { Scale } \bar{x} \mid \mathbf{s}\end{array}$ \\
\hline \multicolumn{6}{|l|}{ Department } \\
\hline Pharmacy & 160 & $4,42 \backslash 0,52$ & $3,18 \backslash 1,07$ & $4,74 \backslash 0,53$ & $4,11 \backslash 0,51$ \\
\hline Nursing & 193 & $4,24 \backslash 0,53$ & $3,61 \backslash 0,06$ & $4,78 \backslash 0,36$ & $4,21 \backslash 0,44$ \\
\hline Health Management & 96 & $4,30 \backslash 0,50$ & $3,81 \backslash 0,9$ & $4,70 \backslash 0,57$ & $4,27 \backslash 0,47$ \\
\hline ANOVA Test (p) & & 0,007 & 0,001 & 0,54 & 0,029 \\
\hline Post Hoc & & $1-2$ & $1-2,1-3$ & & $1-3$ \\
\hline \multicolumn{6}{|l|}{ Gender } \\
\hline Woman & 370 & $4,33 \backslash 0,50$ & $3,59 \backslash 0,91$ & $4,79 \backslash 0,40$ & $4,23 \backslash 0,43$ \\
\hline Man & 79 & $4,28 \backslash 0,64$ & $3,07 \backslash 1,25$ & $4,56 \backslash 0,70$ & $3,97 \backslash 0,58$ \\
\hline T Test (p) & & 0,569 & 0,001 & 0,002 & 0,001 \\
\hline \multicolumn{6}{|l|}{ Grade } \\
\hline $1^{\text {th }}$ & 124 & $4,29 \backslash 0,52$ & $3,47 \backslash 0,91$ & $4,70 \backslash 0,52$ & $4,15 \backslash 0,47$ \\
\hline $2^{\text {nd }}$ & 85 & $4,37 \backslash 0,51$ & $3,57 \backslash 1,00$ & $4,74 \backslash 0,48$ & $4,23 \backslash 0,45$ \\
\hline $3^{\text {rd }}$ & 109 & $4,36 \backslash 0,58$ & $3,49 \backslash 1,12$ & $4,77 \backslash 0,47$ & $4,21 \backslash 0,54$ \\
\hline $4^{\text {th }}$ & 111 & $4,28 \backslash 0,50$ & $3,53 \backslash 0,96$ & $4,80 \backslash 0,33$ & $4,20 \backslash 0,41$ \\
\hline $5^{\text {th }}$ & 20 & $4,27 \backslash 0,53$ & $3,26 \backslash 1,08$ & $4,60 \backslash 0,82$ & $4,04 \backslash 0,54$ \\
\hline ANOVA Test (p) & & 0,619 & 0,765 & 0,992 & 0,493 \\
\hline \multicolumn{6}{|c|}{ Regular Drug Use Status } \\
\hline Yes & 67 & $4,41 \backslash 0,42$ & $3,52 \backslash 0,94$ & $4,77 \backslash 0,55$ & $4,23 \backslash 0,47$ \\
\hline No & 382 & $4,30 \backslash 0,54$ & $3,50 \backslash 1,01$ & $4,74 \backslash 0,046$ & $4,18 \backslash 0,48$ \\
\hline T Test (p) & & 0,089 & 0,856 & 0,148 & 0,429 \\
\hline \multicolumn{6}{|c|}{ Preferring Generic Drugs within the Scope of SSI Reimbursement } \\
\hline Yes & 350 & $4,32 \backslash 0,54$ & $3,52 \backslash 0,98$ & $4,75 \backslash 0,49$ & $4,20 \backslash 0,48$ \\
\hline No & 99 & $4,32 \backslash 0,50$ & $3,42 \backslash 1,07$ & $4,74 \backslash 0,42$ & $4,16 \backslash 0,46$ \\
\hline T Test (p) & & 0,955 & 0,347 & 0,492 & 0,509 \\
\hline \multicolumn{6}{|c|}{ The Situation of Thinking Expensive Medicines Are More Effective } \\
\hline Yes & 31 & $4,00 \backslash 0,53$ & $3,64 \backslash 0,7$ & $4,66 \backslash 0,43$ & $4,10 \backslash 0,41$ \\
\hline No & 418 & $4,34 \backslash 0,52$ & $3,49 \backslash 1,02$ & $4,75 \backslash 0,48$ & $4,20 \backslash 0,48$ \\
\hline T Test (p) & & 0,001 & 0,275 & 0,055 & 0,281 \\
\hline
\end{tabular}

* Since the assumption of normal distribution could not be achieved, Mann Whitney U Test was used when comparing two groups, and Kruskal Wallis Test was used when comparing more than two groups. 
greed with the view that "expensive drugs are more effective" $(\overline{\mathrm{x}}=4.20)$ were higher than those of the students who agreed with it $(\overline{\mathrm{x}}=4.10)$.

Table 6 contains detailed descriptive statistics for the items of the CRDU Scale. According to the data in the table, the items with the lowest level of awareness of the students were the $5^{\text {th }}, 10^{\text {th }}$, and $13^{\text {th }}$ statements containing elements related to the drug recommendation of non-physician health personnel. It was determined that the items with the highest level of awareness were the ones that had elements related to the correct use of drugs and not recommending the same drug to others.

According to the data obtained in the study sample, students who have studied at the Faculty of Health Sciences and Pharmaceuticals are considered to be low due to the fact that the rational level of drug use awareness is the candidate of the health profession.
However, it is generally seen to be at a high level. However, since the dimension with the lowest awareness is "correct drug awareness," it is seen that students take/will take into account the drug recommendations of non-physician healthcare professionals.

The study found that women had higher levels of rational drug use awareness ( $\tilde{x}=4.23-3.97)$. Although it is not correct to speculate on the reasons for this in line with the study data, it is thought to be an indirect consequence of women using more healthcare services.

Another finding of the study is that there is no difference between the levels of rational drug use awareness among the grades studied. In the study, while it was expected that especially the upper grades would have higher awareness levels, it was determined that there was no difference between the grades. It was determined that the grade with the lowest awareness

Table 6. Detailed descriptive statistics on CRDU scale items

\begin{tabular}{|c|c|c|c|c|c|}
\hline Scale Items & $\mathbf{n}$ & Min & Max & $\overline{\mathbf{x}}$ & Sd (s) \\
\hline Drugs that are good for us are also good for our relatives with similar complaints.* & 449 & 1.0 & 5.0 & 4.32 & 0.89 \\
\hline We should take into account the drug recommendations of our relatives..* & 449 & 1.0 & 5.0 & 4.26 & 0.95 \\
\hline $\begin{array}{l}\text { We can safely use, drugs that are good for us in other family members (our children, elderly } \\
\text { members of the family, pregnant women, etc.).* }\end{array}$ & 449 & 1.0 & 5.0 & 4.73 & 0.56 \\
\hline Drugs can be used safely outside of the doctor's recommendation.* & 449 & 1.0 & 5.0 & 4.51 & 0.79 \\
\hline $\begin{array}{l}\text { Other healthcare professionals other than the doctor or pharmacist can be consulted on how } \\
\text { to use the prescribed drugs (dose/amount, fasting/full stomach, etc.).* }\end{array}$ & 449 & 1.0 & 5.0 & 3.49 & 1.28 \\
\hline $\begin{array}{l}\text { Before we go to the doctor, if any, we should try to heal ourselves using the drugs in the } \\
\text { house first.* }\end{array}$ & 449 & 1.0 & 5.0 & 4.27 & 1.00 \\
\hline $\begin{array}{l}\text { If our complaint does not end, we can try other treatments/medications other than those } \\
\text { recommended by the doctor.* }\end{array}$ & 449 & 1.0 & 5.0 & 4.37 & 0.91 \\
\hline $\begin{array}{l}\text { It may be requested from the doctor to add medication to the prescription with the thought } \\
\text { that it may be needed in the future. }\end{array}$ & 449 & 1.0 & 5.0 & 4.41 & 0.92 \\
\hline All treatment methods other than the doctor's recommendation are risky for human health. & 449 & 1.0 & 5.0 & 4.14 & 1.09 \\
\hline Only the doctor must decide which drug we use. & 449 & 1.0 & 5.0 & 3.07 & 1.33 \\
\hline Only the doctor should decide whether it is necessary to use medication. & 449 & 1.0 & 5.0 & 3.84 & 1.29 \\
\hline $\begin{array}{l}\text { Even if they are health personnel (nurse, pharmacist, health officer, etc.), the drug } \\
\text { recommendation of anyone other than the doctor should not be taken into account. }\end{array}$ & 449 & 1.0 & 5.0 & 3.95 & 1.3 \\
\hline $\begin{array}{l}\text { It must be said that even if the doctor did not ask about the drugs we are currently using } \\
\text { when writing the prescription. }\end{array}$ & 449 & 1.0 & 5.0 & 3.17 & 1.36 \\
\hline $\begin{array}{l}\text { Before using our drugs, the paper (prospectus) that comes out of the medicine box must be } \\
\text { read to learn about storage conditions, expected side effects, etc. }\end{array}$ & 449 & 3.0 & 5.0 & 4.69 & 0.74 \\
\hline It is a must to use the drugs we start at the recommended time intervals. & 449 & 1.0 & 5.0 & 4.86 & 0.52 \\
\hline
\end{tabular}

*: These items are reverse coded. The mean values in the table are shown with the answers reversed. 
level was the 5th grade. However, it can be stated that the grades generally have a mean of over 4.04.

In a study with different results from our study findings, Ozyigit et al. [22] examined the rational drug use status of 580 university students and found that most of the students $(76.3 \%)$ did not have rational drug use behavior and that most of them (72.2\%) chose the more expensive drugs with the same effect. Our study found that the majority of the students $(77.9 \%)$ preferred equivalent drugs with more affordable prices, and $93 \%$ of them believed that expensive drugs are not always more effective.

Kartal and Gundogan [23], in a qualitative study on rational drug use with 22 students studying in the departments of Economics, Business Administration, Management Information Systems, and Islamic Sciences of Bartin University, state that most students have not heard the concept of rational drug use, and when they have a disorder, they first try a treatment on their own or by non-drug methods. In the same study, it is stated that the awareness of rational drug use is low in line with the stated ones. However, in terms of sources of information, awareness of students awareness is higher. Our study determined that students had higher awareness of correct usage, unlike the findings of Kartal and Gundogan [23]. However, it can be stated that our study has similar findings in terms of having the lowest mean level of correct drug awareness.

In our study, no significant difference was found between the grades of students in terms of awareness of rational drug usage. Santas and Demirgil [24] stated that the $4^{\text {th }}$ graders have a higher level of awareness about rational drug use than the $1^{\text {st }}$ graders in their study with students studying at the Faculty of Economics and Administrative Sciences of a state university. In the same study, it was stated that $24.3 \%$ of the students did not use the drug on time, and $13.8 \%$ made changes in the dose of the drug. Our study determined that correct usage awareness was high in contrast to this finding. It can be said that students have similar results in terms of low awareness of non-physician drug recommendations $(\tilde{x}=3.50)$ with the finding that students in the study of Santas and Demirgil [24] (42.4\%) were taking medication on advice.

Karaman et al. [25], in their study with 303 Nursing students, found inadequacies in using rational drugs in the questions asked about using the drugs correctly. It was determined that the awareness size of the correct usage of the students in our study was the lower dimension with the highest mean level of awareness $(\tilde{x}=4.75)$.

Soysal and Sahin [26], in their study with 85 Health Management students using the "Rational Drug Use Scale" developed by Ercan, determined that the student's knowledge level about rational drug use was $\bar{x}=3.37$. In the study, no statistically significant difference was found between the rational drug use levels of the students by gender or grade. While it is a common finding in our study that students do not have any difference by grade, it is a thought-provoking finding in the study of Social and Şahin that $4^{\text {th }}$ graders have a lower level of knowledge than other grades $(\bar{x}=2.41)$. It can be said that the significant difference by gender in our study is a finding that does not overlap with the study of Soysal and Sahin [26].

In the study conducted by Kaya et al. [27] with 466 students in order to determine the rational drug use behaviors of university students, it was found that $18 \%$ of the students did not use the drug on time, $25.7 \%$ made a change in the dose of the drug, $27 \%$ used the recommended drug, and gender affected the rational drug use behavior. Although the level of rational drug use was not measured through the scale in the study mentioned above, the percentiles match the findings of our study. Although the groups with low awareness of rational drug use constitute a relative minority, they are at a level that should be emphasized in terms of their effect.

Ozturk and Acar [28] used the "Rational Drug Use Scale" to determine the level of rational drug use of university students, and similar to the findings of our study, they found that women and those with chronic conditions had higher levels of rational drug use. The study states that students have a high level of knowledge about rational drug use in general.

In the study conducted by Buyuker and Odabasi [29] to determine the rational drug use levels of 115 pharmacy technician students studying in the Pharmacy Services program, it is stated that students do not have sufficient knowledge about rational drug use. The study also includes the information that $58 \%$ of the participants do not use the advertised products. In our study, it was seen that the level of awareness of rational drug use among the students of the Faculty of Pharmacy was $\bar{x}=4.11$, and only $2.5 \%$ of the 
Pharmacy students thought that expensive drugs were more effective.

Okyay and Erdogan [30] conducted a study with 960 university students in Kahramanmaraş to determine the rational drug use behaviors of undergraduate students in various faculties other than health sciences. In line with the data obtained by census in the study, it was determined that $36.9 \%$ of the students used drugs other than the physician's recommendation. In the same study, it was determined that only $58.7 \%$ of the students always read the drugs prospectus. In the same study, it was determined that $54.1 \%$ of the students had not heard of the concept of rational drug use before. As a result of their studies, Okyay and Erdogan [30] state that the rational drug use levels of the students included in the research are insufficient.

Kukula [31] conducted a study on rational drug use awareness with 640 medical students at Ondokuz Mayıs University in Samsun. In the mentioned study, it was determined that only $54 \%$ of the students used only the medicines given by the physician, and $25 \%$ of them kept the medicines correctly. In the same study, students were asked whether they had received training on rational drug use. It was determined that $80.78 \%$ of the students did not receive education and $81.56 \%$ of them wanted to receive an education. In Kukula's [31] study, it was found that $31.8 \%$ of the students used the cheaper drug with the same effect and $44 \%$ consumed the drugs belonging to their family members. In the same study, it was reported that $91.56 \%$ of the students informed the physician about the drugs and treatments they used before. Despite this positive finding, the findings regarding the awareness of rational drug use among physician candidate students are thought-provoking.

Sharif et al. [32] In their study, they examined the self-medication levels of 200 students studying pharmacy at the University of Sharjah in the United Arab Emirates. In the study, it is stated that $86 \%$ of the students used self-medication in the past year. In the same study, it is stated that $73 \%$ of the students are not aware of rational drug use. When examining the reasons for self-medicating students, it is stated that in turn, as there is an unserious health problem, reasons such as the need for rapid relaxation, personal attitude, late access to treatment and the cost of treatment are highlighted. Sharif et al. [32] state that self-medication is very common among the students included in the study. In our study, it was determined that the rational drug use awareness level of undergraduate students of the pharmacy was at the level of $\bar{x}=4.11$.

In the study conducted by Burki et al. [6] to determine the rational drug use awareness of 418 university students in Malaysia, it is stated that $38.2 \%$ of the students have poor, $54.9 \%$ have moderate, and $6.9 \%$ have good knowledge of rational drug use. In the study, it is also stated that $77.9 \%$ of the students stopped using drugs after they felt better, and $32.1 \%$ of them took into consideration the people who nonphysician suggested drugs. In line with the data obtained from the students participating in our study, it can be stated that the awareness of rational drug use is higher. However, the idea that the recommend drugs of people other than physician can be taken into account is similar in both groups.

Gunawardhana et al. [33], in a study to determine the awareness of rational drug use by 175 students studying at a university in Sri Lanka, students' knowledge of the dose, frequency, duration, and side effects of antibiotics was found to be moderate $(58.3 \%)$. While there was a significant difference in antibiotic knowledge between health sciences students and students outside the field of health sciences, there was no significant difference in their knowledge levels by gender, grade, and monthly household income. Gunawardhana et al. [33] used a scale with a total score of 12 developed by another author as a data collection tool. In line with the study's findings, it is stated that the rational drug use awareness level of undergraduate students studying health sciences at a university in Sri Lanka is 8.12 out of 12 points. Although the scales used are different, it is estimated that the score obtained in the aforementioned study corresponds to 67.6 when the awareness level of rational drug use is proportioned to 100 in order to make a comparison, and in our study, it is estimated that the awareness level corresponds to 83.8. Although the other elements between the studies are similar, it can be stated that the studies have different findings in terms of the effect of the gender variable on the awareness of rational drug use.

\section{Conclusions}

As a result of the study, it is thought that the students have a relatively good level of awareness with according to the study findings discussed in the literature. However, it is seen that there are inadequacies 
in the correct drug awareness dimension that the drug recommendations of non-physician health personnel can also be taken into account. This situation does not coincide with the individual-specific diagnosis, treatment, drug and dose principle included in the definition of rational drug use, even if they are health professional candidates. The levels of health professional candidates who have insufficient awareness of rational drugs within the average values should not be overlooked, and it is recommended to organize various activities that can increase awareness of rational drug use on students who participate or not participate in the study.

In almost all of the studies mentioned in the discussion part, it is recommended to provide training on rational drug use and to review the programs. Therefore, a well-planned, structured and, organized educational program should be carried out at all levels to promote correct drug use in the community.

Except for two of the studies [26,28] that can be reached in the Turkish literature and measure the level of rational drug use, it was observed that level determination studies were carried out based on qualitative data. It is thought that more objective and comparable measurements can be made by measuring on scales with validity and reliability and by solving and improving the measurement-related problems, if any.

\section{REFERENCES}

1. Sezer Z: Akılcı İlaç Kullanımı ve Farmakoekonomi, Türkiye Klinikleri Aile Hekimliği-Özel Konular 2017, 8(3):224-230.

2. Kalkınma Planı 11 : T.C. Cumhurbaşkanlığı. On Birinci 5 Yı1lık Kalkınma Planı, 2019

3. Aydın B, Gelal A: Akılcı İlaç Kullanımı: YaygınlaştırılmaS1 ve Tıp Eğitiminin Rolü, DEÜ Tıp Fakültesi Dergisi 2012, 16(1):57-63.

4. Ambwani S, Mathur AK: Rational Drug Use, Health Administrator 2006, 19(1):5-7.

5. Hogerzeil HV, Ross-Degnan D, Laing RO, Ofori-Adjei D, Santoso B, Chowdhury AA, ... \& Massele AY: Field Tests for Rational Drug Use In Twelve Developing Countries, The Lancet 1993, 342(8884):408-1410.

6. Burki MR, Shakeel S, Hayat S, Khan AH, Iqbal MS, Khan J: Evaluation of Knowledge, Attitude and Practices of University Students Towards Rational Use of Medicines. Medical Science 2020, 24(106):4425-4437.
7. Aktaş H, Selvi H: Erişkinlerde Akılcı İlaç Kullanımı Farkındalık Ölçeğinin Geliştirilmesi: Geçerlik ve Güvenirlik Ça1ışması. Mersin Üniversitesi Sağlık Bilimleri Dergisi 2019, 12(3):439-447.

8. Şemin S: Sosyal ve Ekonomik Yönleriyle İlaç. Türk Tabipleri Birliği,Ankara,1998.

9. SGK: "Sosyal Güvenlik Kurumu. Topluma Yönelik Akılcı İlaç Kullanımı”, SGK Yayın No: 93, Ankara, 2013

10. TEB Annual : "Türk Eczacıları Birliği Sağlık İlaç ve Eczacılık İstatistikleri Yıllığı 2018”, Ankara, 2018

11. Akıcı A, Uğurlu MÜ, Gönüllü N, Oktay Ş, Kalaça S: Pratisyen Hekimlerin Akılcı Ilaç Kullanımı Konusunda Bilgi ve Tutumlarının Değerlendirilmesi. Sürekli Tıp Eğitimi Dergisi Sted 2002, 11(7):253-257.

12. Vançelik S, Çalıkoğlu O, Güraksın A, Beyhun E: Pratisyen Hekimlerin Reçete Yazımını Şekillendiren Faktörler ve Akılcı Ilaç Kullanım Kriterlerini Önemseme Durumları. Hacettepe Üniversitesi Eczacılık Fakültesi Dergisi 2006, (2):65-76.

13. Khori V, Changizi S, Biuckians E, Keshtkar A, Alizadeh AM, Mohaghgheghi AM, Rabie MR: Relationship Between Consultation Length and Rational Prescribing of Drugs in Gorgan City, Islamic Republic of Iran.EMHJ-Eastern Mediterranean Health Journal 2012, 18(5):480-486.

14. Hocaoğlu N, Güven H, Gidener S, Kalkan Ş, Gümüştekin M, Gelal A: Dokuz Eylül Üniversitesi Tıp Fakültesi Dördüncü Sınıf Öğrencilerinin Akılcı Ilaç Kullanım Becerileri Üzerine Akılcı Ilaç Kullanım Kursunun Kısa Dönem Etkileri. Dokuz Eylül Üniversitesi Tıp Fakültesi Dergisi 2011, 25(1):15-24.

15. TCSB Annual: "T.C. Sağlık Bakanlığı Sağlık İstatistikleri Yıllı̆̆ 2018”, Ankara (2019)

16. Turkrating Report : "Turk Rating Sektör Raporları: Türkiye İlaç Sektörü Mayıs,2020”, Available from: http://turkrating. com/files/uploads/ilac-sektoru-mayis-2020-6870.pdf (Access date: 25 December 2020)

17. Pınar N: Ülkemizde İlaç Harcamaları. İnönü Üniversitesi Tıp Fakültesi Dergisi 2012, 19(1):59-65.

18. Tabachnick BG, Fidell LS: Using Multivariate Statistics. Boston, Pearson Press. 2013, Vol.6

19. Kılıç S: Cronbach'ın Alfa Güvenirlik Katsayısı. Journal of Mood Disorders 2016, 6(1):47-48.

20. Karagoz Y: SPSS-AMOS-META Uygulamalı Istatistiksel Analizler. Nobel; Ankara

21. Topkara FN, Cagan O: Dogum Hafizası ve Hatırlama Olcegi Turkce versiyonunun psikometrik özelliklerinin incelenmesi. Psikiyatri Hemsireligi Dergisi 2021, 12(3):245-253

22. Özyiğit F, Arıkan İ: Kütahya İlinde Üniversite Öğrencilerinin Akılcı İlaç Kullanımı Hakkında Bilgi, Tutum ve Davranışlar1. Bozok Tıp Dergisi 2015, 5(1):47-52. 
23. Kartal SE, Gündoğar HS: Üniversite Öğrencilerinin Akılcı İlaç Kullanımı Hakkındaki Görüşleri. Bartın Üniversitesi Eğitim Araştırmaları Dergisi 2017, 1(1):25-34.

24. Şantaş F, Demirgil B: Akılcı İlaç Kullanımına Ilişkin Bir Araştırma. İşletme Bilimi Dergisi 2017, 5(1):35-48.

25. Karaman A, Ayoğlu T, Aydoğan MN, Kuğu E: Hemşirelik Öğrencilerinin Akılcı İlaç Kullanma Durumları. FNJN Florence Nightingale Journal of Nursing 2019, 27(2):143-156.

26. Soysal A, Şahin E: Akılcı Ilaç Kullanımı: Üniversite Öğrencileri Üzerinde Bir Araştırma. Sağlık Akademisyenleri Dergisi 2020, 7(3):175-182.

27. Kaya H, Turan N, Keskin O, Tencere Z, Uzun E, Demir G, Yilmaz T: Üniversite Öğrencilerinin Akılcı İlaç Kullanma Davranışları. Anadolu Hemşirelik ve Sağlık Bilimleri Dergisi 2015, 18(1):35-42.

28. Öztürk H, Acar F: Yükseköğretim Öğrencilerinin Akılcı İlaç Kullanımına Yönelik Algı ve Tutumlarının Değerlendirilmesi: Bir Devlet Üniversitesi Örneği. Uluslararası Sağlık Yönetimi ve Stratejileri Araştırma Dergisi 2021, 7(1):32-46.
29. Buyuker SM, Odabasi G: Assessment of Knowledge and Behaviour of Pharmacy Services Students in Vocational School of Health Services for Rational Drug Use. Eastern Journal of Medical Sciences 2018, 3(3):28-33.

30. Okyay RA, Erdogan A: Self-medication practices and rational drug use habits among university students: a cross-sectional study from Kahramanmaraş, Turkey. Peer Journal 2017, 5(e3990)

31. Kukula O: Evaluation of knowledge and behaviors of students in faculty of medicine towards rational drug use. Turkish Journal of Clinics and Laboratory 2012, 10(3):294-300

32. Sharif SI, Ibrahim OHM, Mouslli L, Waisi R: Evaluation of self-medication among pharmacy students. American Journal of Pharmacology and Toxicology 2012, 7(4):135-140.

33. Gunawardhana CB, Sakeena MHF, Sivayoganthan C: Awareness of Rational Medication Use and Antibiotic SelfMedication Practices Among Undergraduate Students in A University in Sri Lanka. Tropical Journal of Pharmaceutical Research 2015, 14(4):723-729. 